\title{
Felső ugróízülettel kommunikáló csontcysta sebészi kezelése súlyos A-haemophiliás betegen
}

\author{
Kovács Krisztián dr. - Bartha Lajos dr. - Antal Imre dr. \\ Semmelweis Egyetem, Általános Orvostudományi Kar, Ortopédiai Klinika, Budapest
}

\begin{abstract}
A szerzők egy ritka antitestpozitivitással járó VIII.-faktor-hiányos beteg esetét ismertetik, akinél fájdalmas mozgáskorlátozottságot okozó bokaízületi bevérzések jelentkeztek 2-3 hetes gyakorisággal. A beteg MR-felvételei alapján diagnosztizálták, hogy a bal tibia distalis végét és a belbokát is beszứrố cysta a tibiotalaris ízfelszínt erodálva kis nyíláson át kommunikál a felső ugróízülettel. A cysta mérete, lokalizációja miatt fennállt egy ízületi felszínt is érintő patológiás törés veszélye. A beteg kezelését a hiányzó véralvadási faktor ellen a szervezetében magas koncentrációban képződő autoantitestek nehezítették. A törésveszély és a recidív bevérzések megszüntetése érdekében a cysta feltárása, falának kikaparása és az üreg csontallografttal történő kitöltése mellett döntöttek. A mútét alatt és a posztoperatív szakban a beteg rekombináns faktorkészítményt kapott, a szokásos thromboprophylaxis mellett. A vérzéses komplikáció jelentős kockázata ellenére a betegnek sem vérzéses, sem thromboemboliás szövődménye nem volt, mútéte óta felső ugróízületi haemarthrosisa sem ismétlődött. A szerző́k az eset ismertetésével felhívják a figyelmet erre az életminőséget megnehezítő ritka betegségre, az ellátásához szükséges komprehenzív haemophiliaközpontokra és az összehangolt multidiszciplináris kezelés fontosságára.
\end{abstract}

Orv Hetil. 2019; 160(17): 679-682.

Kulcsszavak: haemarthrosis, haemophilia, patológiás törés, alvadási faktor

\section{Surgical treatment of a juxtaarticular bonecyst communicating with the ankle joint in a severe haemophilia $A$ case}

The authors report the case of a 19-year-old male patient with inhibitor-positive factor VIII deficiency. The patient had painful, limited range of motion and swelling in the left toe, due to haemarthrosis 1-2 times a month. The MR images depicted a bone cyst penetrating into the tibiotalar joint space at the distal end of the left tibia. Due to the size and localisation of the cyst, there was a high chance of a pathological fracture with a potential intraarticular component. The clinical scenario was complicated by the high level of antifactor VIII antibodies. To prevent pathological fracture and stop the recurrence of haemarthrosis, the authors decided to debride the cavity and fill it with bone chips. During the operation and the postoperative period the patient recieved recombinant clotting factor substitution and standard thromboprophylaxis. Despite the high risk of bleeding complication, the patient had neither bleeding nor thomboembolic complication. Further bleeding into the joint space has not been reported by the patient since the surgery. The authors aim to draw attention to this rare, but significant disease, the role of the haemophilia centers and the importance of the coordinated multidisciplinary treatment.

Keywords: haemarthrosis, haemophilia, pathological fracture, clotting factor

Kovács K, Bartha L, Antal I. [Surgical treatment of a juxtaarticular bonecyst communicating with the ankle joint in a severe haemophilia A case]. Orv Hetil. 2019; 160(17): 679-682. 


\section{Rövidítések}

APCC $=($ activated prothrombin complex concentrate $)$ aktivált protrombinkomplex-koncentrátum; autoAT = autoantitest; $\mathrm{IgG}=$ immunglobulin-G; $\mathrm{MRI}=$ (magnetic resonance imaging) mágnesesrezonancia-vizsgálat; $\mathrm{PCC}=$ (prothrombin complex concentrate) protrombinkomplex-koncentrátum; rFVIIa $=($ recombinant activated factor VII $)$ rekombináns aktivált VII. faktor; $\mathrm{rtg}=$ röntgen

A haemophilia egy X-kromoszómához kötött, recesszív öröklődésú véralvadási zavar [1]. Leggyakoribb formája az A-típusú haemophilia, amelyet a VIII. alvadási faktor csökkent szintje okoz. Minden 5000 fiúgyermek közül [2] egynél alakul ki a betegség. Kevésbé súlyos esetekben az alvadási idő megnyúlásával, kisebb baleseteket követően a haematomák elhúzódó felszívódásával járnak. Súlyosabb esetekben az ízületekbe és izmokba történő spontán bevérzések is előfordulnak. Hazánkban ez utóbbiak megelőzésére a legkorszerúbb prophylacticus szubsztitúciót is bevezették, ugyanakkor az „on demand" (kérésre) módszer létjogosultsága is változatlanul fennáll. A faktor pótlására nagy tisztaságú plazma- és rekombináns készítmények állnak rendelkezésre. A szubsztitúciós kezelést jelentősen megnehezíti, sok esetben lehetetlenné teszi, ha a szervezetben faktorellenes antitestek, úgynevezett inhibitorok képződnek. Ezek az A-haemophilia esetén a VIII. faktor ellen képződő polyclonalis magas affinitású immunglobulin-G (IgG)típusú antitestek.

Az inhibitorképződés ritka, a súlyosabb és középsúlyos A-haemophilia esetén gyakoribb a megjelenése [3]. A súlyos A-haemophilia-esetek 20-30\%-ánál keletkeznek VIII.-faktor-ellenes autoantitestek [4]. Ezen autoantitestek kimutatása a Bethesda-inhibitorteszt segítségével történik. Minél magasabb az inhibitortiter, annál súlyosabb a kórkép. Az alacsony titerrel járó inhibitoros ese- tekben a gyakoribb VIII.-faktor-pótlás is elegendő lehet a megfelelő vérzéscsillapítás eléréséhez. A magasabb titerú, súlyosabb esetekben azonban a gyakoribb pótlás ellenére az autoantitestek semlegesítik a beadott faktort. Életet veszélyeztető vérzés esetén plazmaferézissel vagy immunadszorpciós technikával eliminálhatók ugyan a gátlótestek, ez a megoldás azonban csupán átmeneti, mivel a beadott faktor ellen napok alatt ismételten nagy mennyiségben autoantitestek jelennek meg. Ilyenkor alternatív kezelést célszerú alkalmazni (bypassterápia) [5], figyelembe véve a vérzés súlyosságát, a beteg életkorát, inhibitorkarakterisztikáját, vagyis a beteg egyéni farmakokinetikai sajátosságait. Mind a haemophilia A- és B-típusánál a bypassterápia a felsorolt 2 készítmény adásának valamelyikét jelenti, legyen az aktivált protrombinkomplex-koncentrátum (APCC) vagy a rekombináns aktivált VII. faktor (rFVIIa) adása.

Az alvadási szempontból nem megfelelően beállított és visszatérően az ízületbe törő vérzéses hemofíliás betegek esetén hosszú távon az ízületi porc rapid károsodása, pusztulása következik be, melynek megoldására a protézisbeültetés jön szóba. A recidív bevérzések során célízületek jönnek létre, ami azt jelenti, hogy általában ugyanazon ízületek véreznek be ismétlődő jelleggel. A vérzések gyakorisága szerint a térd-, a könyök- és a bokaízületek vannak kitéve a hemofíliás arthropathiának [6]. Az ízületi károsodások következtében fájdalom, deformitás és az ízületfunkció vesztésének markáns progressziója figyelhető meg. Amennyiben a deformitás és a panaszok mértéke már nem engedi meg azok konzervatív kezelését, úgy az ízület protetizálása, illetve amennyiben ez nem lehetséges, az ízület elmerevítése a választandó módszer [7].

A 19 éves, erôsen túlsúlyos $(\mathrm{BMI}=35)$ férfi beteget a három hónapja tartó, heti rendszerességgel jelentkező bal boka táji fájdalmas duzzanata miatt utalták intéz-
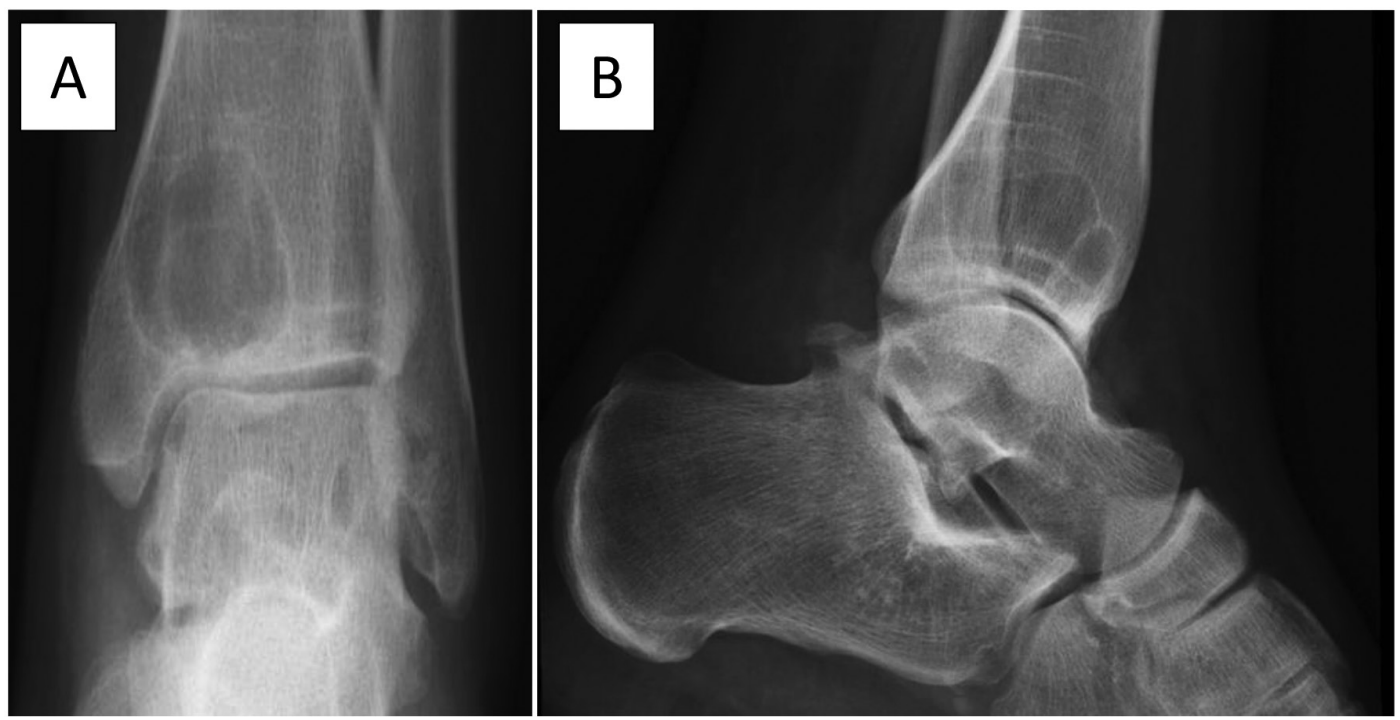

1. ábra

| A bal boka preoperatív anterioposterior röntgenfelvétele (A), oldalfelvétel (B) 
ményünkbe. Kétéves kora óta ismeretes a hemofíliája. A rendszeres bevérzések a felső ugróízület jelentős mozgásbeszúkülését okozták. A mozgástartomány nagymértékben beszúkült a fájdalom és a nagymértékü károsodás miatt.

\section{Módszer}

A betegnél a röntgenfelvételek (1. ábra) a bal tibia distalis végének cystosus elváltozását mutatták, amely felvetette a cysta lumenének és a felső ugróízületi tér közötti kommunikációnak a gyanúját. Ennek pontosabb megítélésére MRI-vizsgálat történt (2. ábra), amely a gyanút alátámasztotta. A preoperatív kivizsgálások részeként Bethesda-teszt készült, amelynél diagnosztizálásra került a VIII. faktor elleni magas titerü inhibitorszint. Mivel a
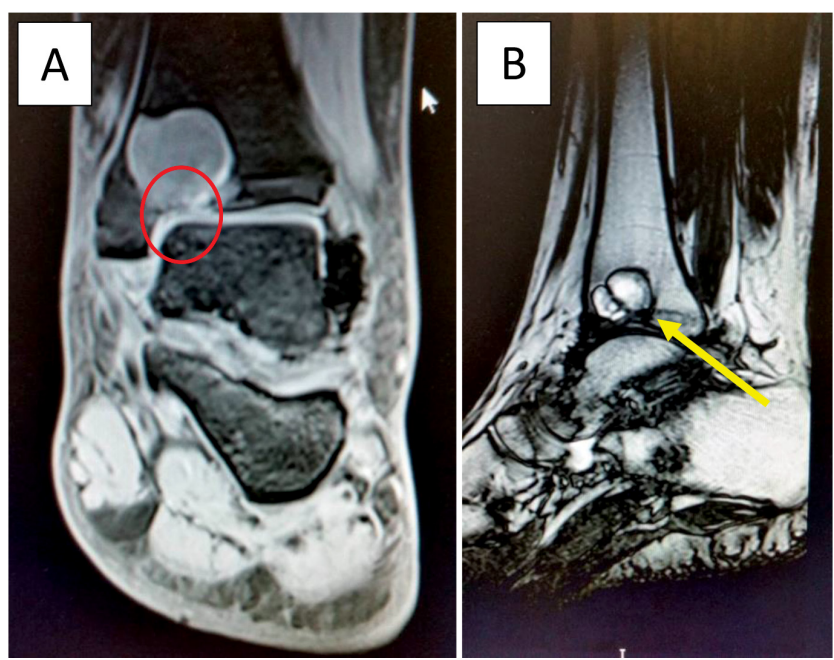

2. ábra

A bal boka preoperatív MRI-képei, melyeken jól látható a cysta kommunikációja az ízületi réssel (piros ellipszis [A], T2-súlyozás), valamint a cysta septummal elválasztott cavuma (sárga nyíl [B], Tl-súlyozás) farmakokinetikai vizsgálatok alapján a beteg immunológiai szempontból alkalmatlan volt az APCC-bypass-kezelésre, a betegnél a jelentősen drágább módszer, a rekombináns VII. faktor pótlása került alkalmazásra.

A látott képek alapján a benignus morfológiát mutató differenciáldiagnosztikai szempontból elsősorban a hemofíliás csontcysta és a juxtaarticularis csontcysta lehetősége merült fel. Nem volt kizárható azonban egy esetleges óriássejtes csonttumor vagy aneurizmás csontciszta, noha a rendszeres bevérzések inkább hemofíliás csontcystára utaltak.

\section{Eredmények}

Az inhibitoros beteg folyamatosan ismétlődő ízületi bevérzéseinek kezelésére a legtöbb esélyt a mütéti beavatkozás jelentette. A rekombináns VII. faktornak a megfelelő hemoszteziológiai perioperatív szubsztitúciós protokoll alapján beállított adását és a szokásos preoperatív mûtéti előkészítést követően elvégeztük a beavatkozást. A cisztát feltártuk, és falának gondos eltávolítását követően az üreget csontbankból származó fagyasztott femurfejből nyert spongiosus csontallografttal töltöttük fel (3. ábra). A feltárás során endoszkópos eszközzel is ellenőriztük a kommunikációt a felső ugróízület és a cysta ürege között (4. ábra). A posztoperatív időszakban a betegnél szigorú tehermentesítést rendeltünk el az ízületi terhelési felszínhez közeli elhelyezkedésre való tekintettel 4 hétre, majd további két hét részterhelést engedtünk. A mütétet fél évvel követő röntgenfelvételeken (5. ábra) a beültetett csont teljes értékủ átépülését észleltük, amely lehetôvé tette az ízület teljes testsúly melletti használatát . Az ilyen mütétet követően a leggyakoribb szövődmények az elhúzódó sebgyógyulás és az allergiás reakciók [8], melyek közül betegünknél egyik sem fordult elő. A mütét óta fájdalmai megszűntek, bevérzései, bokatáji duzzanatai nem ismétlődtek.
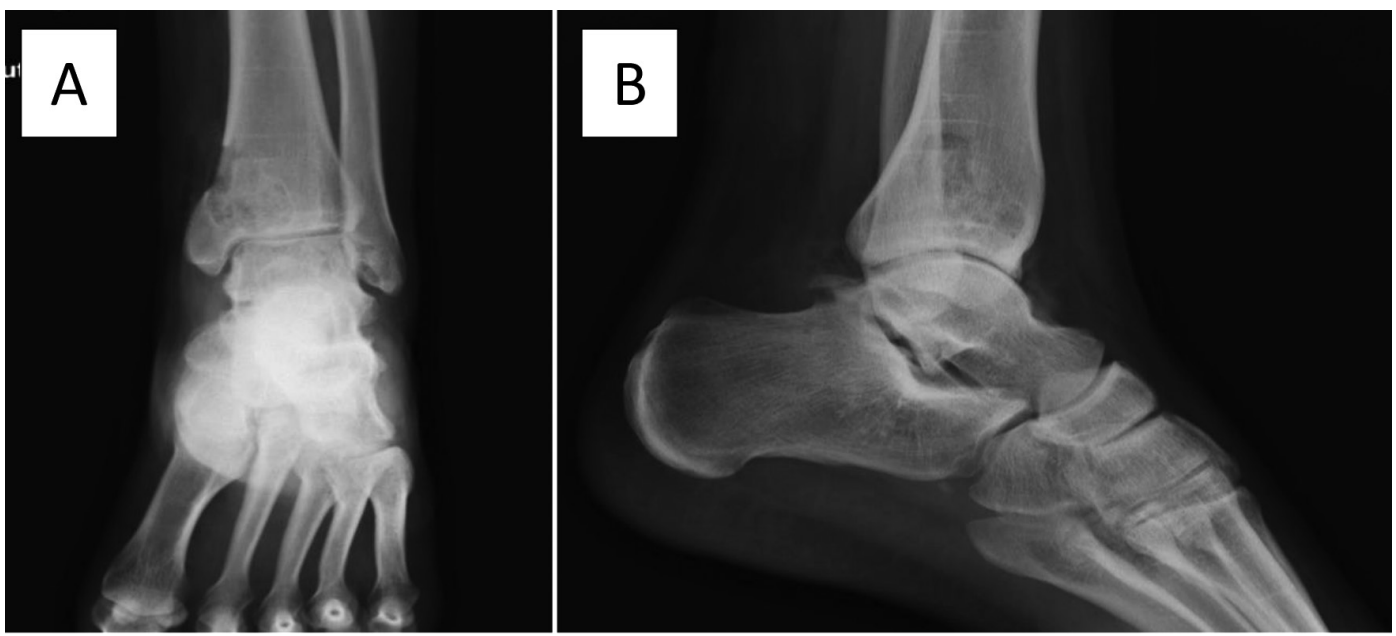


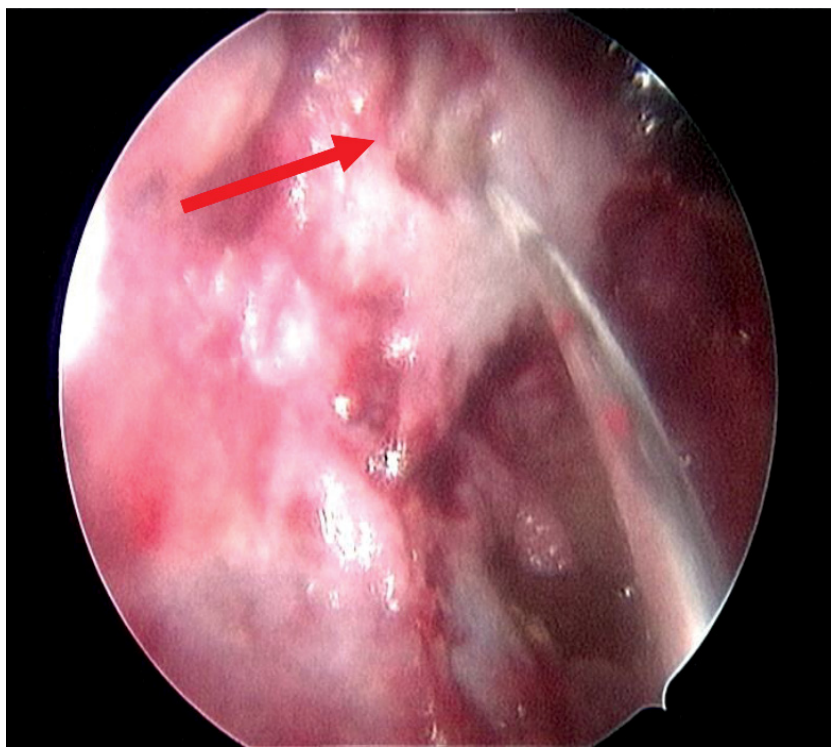

4. ábra

Endoszkópos intraoperatív kép; a szonda hegyénél (nyíl) a cysta ürege a felső ugróízülettel kommunikál

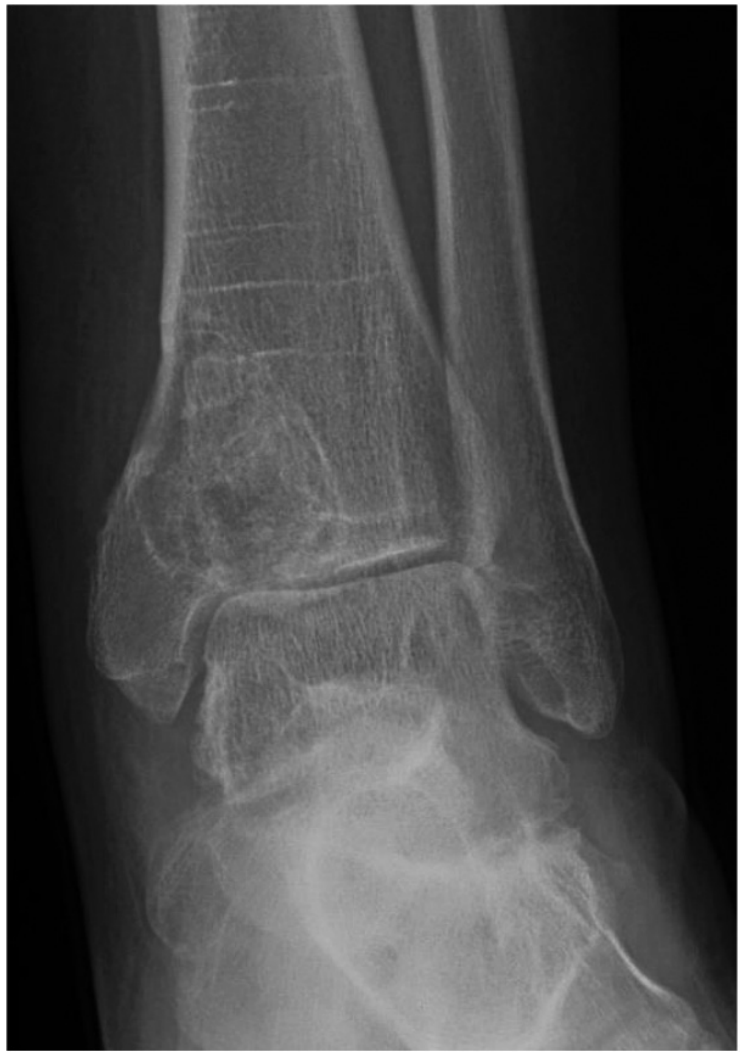

5. ábra

A bal boka féléves posztoperatív anterioposterior röntgenfelvétele

\section{Megbeszélés}

A vérzési zavarok közül az A-típusú haemophilia fordul elő a leggyakrabban. Kezelésének komoly nehézségeket okozó komplikációja a gátlóantitest-képződés a pótlásra adott faktorral szemben. Ezeket a betegeket a haemophilia centrumokkal szoros együttmúködésben ajánlatos kezelni. Esetünk is azt példázza, hogy az ezeket a betegeket érintő sebészi beavatkozások során elengedhetetlen a társszakmák interdiszciplináris együttmúködése.

Anyagi támogatás: A közleménnyel kapcsolatos kutatómunka anyagi támogatásban nem részesült.

Szerzői munkamegosztás: K. K.: Irodalomkutatás, a kézirat elkészítése. B. L., A. I.: Az operáció végzése, a szöveg szakmai lektorálása. A cikk végleges változatát mindhárom szerző elolvasta és jóváhagyta.

Érdekeltségek: A szerzőknek nincsenek érdekeltségeik.

\section{Irodalom}

[1] Witmer C, Young G. Factor VIII inhibitors in hemophilia A: rationale and latest evidence. Ther Adv Hematol. 2013; 4: 59-72.

[2] Soucie JM, Evatt B, Jackson D. Occurrence of hemophilia in the United States. The hemophilia surveillance system project investigators. Am J Hematol. 1998; 59: 288-294.

[3] DiMichele DM. Inhibitors in haemophilia: a primer. Haemophilia 2000; 6(Suppl 1): 38-40.

[4] Oldenburg J, Young G, Santagostino E, et al. The importance of inhibitor eradication in clinically complicated hemophilia A patients. Expert Rev Hematol. 2018; 11: 857-862.

[5] Li R, Panckeri KA, Fogarty PF, et al. Recombinant factor VIIa addition to hemophilic blood perfused over collagen/tissue factor can sufficiently bypass the factor IXa/VIIIa defect to rescue fibrin generation. Haemophilia 2017; 23: 759-768.

[6] Eckers F, Bauer DE, Hingsammer A, et al. Mid- to long-term results of total ankle replacement in patients with haemophilic arthropathy: a 10-year follow-up. Haemophilia 2018; 24: 307315.

[7] Bluth BE, Fong YJ, Houman JJ, et al. Ankle fusion in patients with haemophilia. Haemophilia 2013; 19: 432-437.

[8] He Y, Zhou X, Cui H, et al. Surgical management of haemophilic pseudotumors: experience in a developing country. $\mathrm{J}$ Invest Surg. 2017 Nov 2. DOI: 10.1080/08941939.2017. 1386737. [Epub ahead of print]

(Kovács Krisztián dr., Budapest, Üllői út 78/B, 1082 e-mail: coconut_c@msn.com)

A cikk a Creative Commons Attribution 4.0 International License (https://creativecommons.org/licenses/by/4.0/) feltételei szerint publikált Open Access közlemény, melynek szellemében a cikk bármilyen médiumban szabadon felhasználható, megosztható és újraközölhető, feltéve, hogy az eredeti szerző és a közlés helye, illetve a CC License linkje és az esetlegesen végrehajtott módosítások feltüntetésre kerülnek. (SID_1) 